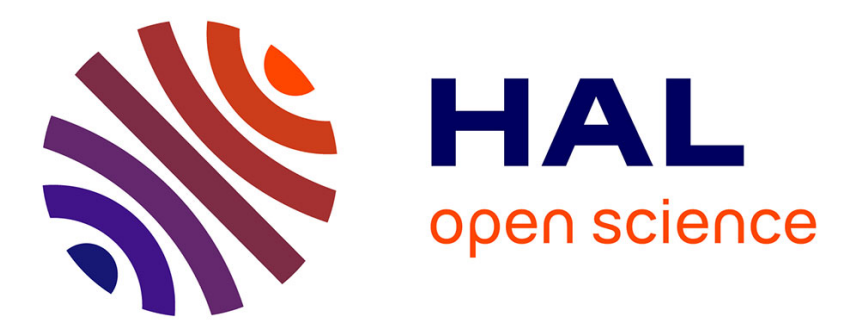

\title{
Immunogenicity of HIV Type 1 gp120 CD4 Binding Site Phage Mimotopes
}

Karim Dorgham, Ismaïl Dogan, Natacha Bitton, Christophe Parizot, Valerie Cardona, Patrice Debré, Oliver Hartley, Guy Gorochov

\section{To cite this version:}

Karim Dorgham, Ismaïl Dogan, Natacha Bitton, Christophe Parizot, Valerie Cardona, et al.. Immunogenicity of HIV Type 1 gp120 CD4 Binding Site Phage Mimotopes. AIDS Research and Human Retroviruses, 2005, 21 (1), pp.82-92. 10.1089/aid.2005.21.82 . hal-02481826

\section{HAL Id: hal-02481826 \\ https://hal.science/hal-02481826}

Submitted on 17 Feb 2020

HAL is a multi-disciplinary open access archive for the deposit and dissemination of scientific research documents, whether they are published or not. The documents may come from teaching and research institutions in France or abroad, or from public or private research centers.
L'archive ouverte pluridisciplinaire HAL, est destinée au dépôt et à la diffusion de documents scientifiques de niveau recherche, publiés ou non, émanant des établissements d'enseignement et de recherche français ou étrangers, des laboratoires publics ou privés. 


\title{
Immunogenicity of HIV-1 gp120 CD4 Binding Site Phage Mimotopes
}

\author{
Karim Dorgham ${ }^{1}$, Ismaïl Dogan ${ }^{1}$, Natacha Bitton ${ }^{1}$, Christophe Parizot ${ }^{1}$, Valerie \\ Cardona $^{2}$, Patrice Debré ${ }^{1}$, Oliver Hartley ${ }^{2}$, Guy Gorochov ${ }^{1 *}$.
}

1 - Immunologie A, CERVI, INSERM U543, Hôpital Pitié-Salpêtrière, Paris, France

2 - Département de Biochimie Médicale, Centre Médical Universitaire, Geneva, Switzerland.

* Corresponding author.

Mailing address: Dr. Guy Gorochov, M.D, Ph.D.

Unité INSERM 543,

CERVI, Hôpital Pitié-Salpêtrière,

83 Bd. de L’Hôpital, 75013,

Paris, France.

Telephone: 33142177507 .

Telefax: 33142177490 .

E-mail: guy.gorochov@psl.ap-hop-paris.fr. 


\section{ABSTRACT}

The conserved domain of the CD4 binding site (CD4bs) on the human immunodeficiency virus type 1 (HIV-1) envelope represents a potential target for vaccine development. Here we describe selection of peptide mi-motopes by panning a phage peptide library on the HIV-1 CD4bs-specific, broadly neutralizing anti-HIV-1 monoclonal antibody, IgGl b12. We identified an initial consensus sequence for IgG1 b12 binding (M/V $\Theta S D$, where $\Theta$ represents an aromatic amino acid). A molecular evolution approach, using second- and third-gen-eration libraries, led us to identify a refined consensus sequence (GLLVWSDEL). The resulting IgG1 b12 phage mimotopes compete with gp160 for the IgG1 b12 antigenbinding site, but the phage coat protein (pIII) may play an important structural role, since both free peptides and KLH-conjugated peptides have no de-tectable binding activity. Mice immunized with IgG1 b12 phage mimotopes elicited a weak but persistent hu-moral response directed against the HIV-1 envelope. An antibody fragment was isolated from the antibody repertoires of these animaIs. It is noteworthy that while it has a relatively low affinity for HIV-1 gp160, the antibody targets an epitope that overlaps with that of IgG1 b12. Our data therefore suggest that engineered IgG1 b12 mimotopes share immunogenic features with the CD4bs. However, these peptidic structures will re-quire further improvement in order to generate broad specificity neutralizing antibodies like IgG 1 b12.

Abbreviations used: $\mathrm{CD} 4 \mathrm{bs}, \mathrm{CD} 4$ binding site ; $\mathrm{ScFv}$, Single-chain variable fragment ; PBSM, Phosphate Buffer Saline with 3\% (w/v) milk powder; PBST, PBS with 0,1\% Tween 20 ; CFA, Complete Freund Adjuvant ; IFA, Incomplete Freud Adjuvant. 


\section{INTRODUCTION}

The Human Immunodeficiency Virus type 1 (HIV-1) interacts with target cells by virtue of a high-affinity interaction between host cell CD4 and the viral envelope glycoprotein (Env), which is formed by cleavage of the glycoprotein (gp)160 precursor into two non-covalently associated polypeptide chains, gp120 and gp41. ${ }^{1}$ The HIV-1 envelope is currently the major focus in the design of HIV-1 humoral vaccines and antigen-based immunotherapeutic strategies.

Two functionally and temporally distinct classes of neutralizing antibodies (Abs) are generated against HIV-1 in infected humans. Highly strain-specific antibodies are elicited early after initial infection. Later in the course of infection, antibodies capable of neutralizing a wider range of HIV-1 isolates appear, but cross-neutralizing titers remain typically low. ${ }^{2-4}$ Attempts to induce a broadly protective antibody response against genetically diverse HIV-1 isolates have not been successful. ${ }^{5-10}$ This can be explained in part by continuous in vivo evolution of the virus (viral escape, interclade recombinations, and emergence of new viral isolates), which leads to a high degree of antigenic polymorphism. Moreover, potential neutralizing epitopes on gp120 are occluded by genetically variable loops, ${ }^{11,12}$ extensive glycosylation, ${ }^{13-15}$ and subunit interactions within the trimeric structure of the mature HIV -1 envelope. ${ }^{16-18}$

The poor accessibility of broadly neutralizing epitopes probably explains why human monoclonal antibodies (mAbs) that neutralize primary viral isolates in a broad crossclade manner have proven difficult to isolate. ${ }^{15}$ Only five such human mAbs have currently been identified. The epitope of one such antibody, IgG1 b12, has previously been studied using different approaches including gp120 mutagenesis, ${ }^{19}$ crystallography, ${ }^{20,21}$ or phage display technology. ${ }^{22,23}$ It has been revealed to be a discontinuous epitope that overlaps the CD4 binding site (CD4bs) on gp120. ${ }^{24,25} 2 \mathrm{G} 12 \mathrm{mAb}$ recognizes a glycan discontinuous epitope involving the $\mathrm{C} 3-\mathrm{V} 4$ region of gp120. ${ }^{26-28}$ The antibody fragment Fab X5, which binds to a CD4-induced (CD4i) epitope, was obtained, like IgG 1 b12, after selection of a phage 
display library against a CD4-gp120-CCR5 complex. ${ }^{29}$ Finally, 2F5 $5^{30-32}$ and z13/4el0 ${ }^{30,33}$ mAbs bind epitopes on the ectodomain of gp41.

Passive immunization studies in hu-PBL-SCID mice ${ }^{34,35}$ and nonhuman primate models ${ }^{36-}$

${ }^{39}$ have shown that high doses of Env-targeted neutralizing antibodies can prevent infection. However, no immunogen capable of eliciting broadly neutralizing Abs has been engineered so far. Elucidation of neutralizing epitope structures may offer valuable insights into the design of such potentially important compounds.

The goal of this study was to identify immunogenic structures that elicit a broad specificity, neutralizing humoral anti-HIV-1 response by screening a phage-displayed peptide library on the anti-CD4bs mAb, IgGl b12. Our results confirm and extend previously published data defining consensus sequences for the epitope of this antibody. ${ }^{23}$ Most importantly, we show that immunization of mice with phage displaying IgG1 b12 mimotopes induces gp120-specific antibodies.

\section{MATERIALS AND METHODS}

Antibodies and purified proteins

MAbs IgG1 b12, F105, ${ }^{40}$ and recombinant proteins HIV-1SF2 gp120, HIV-lMN gp120, HIV-1CM gp120, HIV-IIIIB (LAV) gp120, HIV-lMN gp160 MN, and soluble CD4 (sCD4) were obtained through the AIDS Research and Reference Reagent Program, Division of AIDS, NIAID, NIH. Control proteins ferritin, KLH, and BSA were obtained from Sigma.

\section{Phage-peptides}

A peptide library displayed on minor coat protein (pIII) was kindly provided by Igor Fisch and Greg Winter, MRC, Centre for Protein Engineering, Cambridge, UK. This library consists of two recombined repertoires of random decamers, joined together through a central five-residue spacer (ALLRY) and fused to the pIII coat protein of the 
bacteriophage. ${ }^{41}$ A control phage displaying tag HA1.1 (YPYDVPDYA)-pIII fusion was constructed by cloning an appropriate DNA insert into the phage vector fdMED $1^{42}$ (kindly provided by I. Fisch) between restriction sites $S f i$ and NotI. FdMEDl is derived from the fdDOG1 vector. ${ }^{43}$ For alanine scanning, DNA inserts bearing mutations were introduced into FdMEDl clones. Phage dsDNA vectors were purified with QIAprep Spin Miniprep Kit (Qiagen, Courtaboeuf, France) from overnight bacterial cultures. DNA vectors were electroporated into Escherichia coli XLI blue (Stratagene, La Jolla, CA). DNA sequencing was performed using an ABI Prism 377 automatic sequencer (Perkin Elmer, Norwalk, CT).

\section{Biopanning}

For phage selection, 5-ml polystyrene tubes (Becton Dickinson, Lincoln Park, NJ) were coated overnight at $4^{\circ} \mathrm{C}$ with $50 \mu \mathrm{g}$ of protein in $2 \mathrm{ml}$ phosphate-buffered saline (PBS). Tubes were washed twice with PBS and blocked with PBS-3\% low-fat milk (PBSM) for 2 $\mathrm{hr}$ at room temperature. Input phage, $10^{12}$ colony-forrning units (cfu) that had previously been blocked in $2 \mathrm{ml}$ of PBSM were added to the tubes and incubated for $4 \mathrm{hr}$ at room temperature. Unbound phage were removed by washing 10 times with PBS $0.1 \%$ Tween 20 (PBST) and 10 times with PBS. E. coli TGl suspension at mid-log phase (OD600 = 0.6) was added directly into each tube and incubated for $1 \mathrm{hr}$ at $37^{\circ} \mathrm{C}$ with vigorous shaking. The bacteria were then plated onto LB petri dishes containing tetracycline $(15 \mu \mathrm{g} / \mathrm{ml})$ and incubated overnight at $37^{\circ} \mathrm{C}$. Infected bacteria were scraped from plates and collected in 50 $\mathrm{ml}$ of $2 \mathrm{YT}$ broth, incubated for $2 \mathrm{hr}$ at $37^{\circ} \mathrm{C}$, and then diluted $1 / 500$ in $2 \mathrm{YT}$ broth and cultured overnight. Phage were then purified and titered as previously described. ${ }^{41,44}$ After each round of biopanning, isolated clones were randomly picked from LB agar plates and grown overnight at $30^{\circ} \mathrm{C}$ in 96- well plates (ATGC Biotechnologie, Noisy le Grand, France) filled with $200 \mu \mathrm{l}$ of $2 \mathrm{YT} /$ tetracycline. Plates were centrifuged (250 X g, $10 \mathrm{~min})$ and the supernatants used directly for phage enzyme-linked immunosorbent assay (ELISA). 


\section{Phage ELISA and competition assays}

Ninety-six-well Maxisorp immunoplates (NUNC, Roskilde, Denmark) were coated overnight at $4^{\circ} \mathrm{C}$ with $0.2 \mu \mathrm{g}$ of $\mathrm{mAb}$ in PBS/well. After three washes in PBS, plates were incubated $1 \mathrm{hr}$ at $37^{\circ} \mathrm{C}$ with PBSM. Dilutions of phage or culture supernatants $(100 \mu \mathrm{l})$ were blocked with $100 \mu \mathrm{l}$ of PBSM and incubated in plates for $1 \mathrm{hr}$ at $37^{\circ} \mathrm{C}$. For competition assays, CsCl-purified phage were added to each well in a volume of $100 \mu 1$ of PBSM. Soluble gp120 was then added in a $50 \mu 1$ volume of PBSM to reach final concentrations of 1,5 , or $10 \mu \mathrm{g} / \mathrm{ml}$ and plates were also incubated for $1 \mathrm{hr}$ at $37^{\circ} \mathrm{C}$. Plates were then washed three times with PBST followed by three more with PBS and wells were incubated for $1 \mathrm{hr}$ at $37^{\circ} \mathrm{C}$ with $100 \mu \mathrm{l}$ of HRP-conjugated anti-M13 (Amersham, Saclay, France; 1/5000 in PBSM). Plates were again washed (three times PBST, three times PBS) and developed with $100 \mu 1$ of ImmunoPure TMB Substrate Kit (Perbio Science, Bezon, France) according to the manufacturer' s instructions.

\section{Free peptide mimotopes}

Mimotope peptides, with N-termini blocked by acetylation and C-termini blocked by amidation, were synthesized by Boc-based solid-phase peptide synthesis on methylbenzhydrylamine resin and purified by reverse-phase high-performance liquid chromatography to reach a purity of at least $95 \%$. Peptide identity was confirmed by mass spectrometry (MALDI/TOF).

\section{Immunization of mice}

Five-week-old female C57BL/6 (Iffa Credo, Lyon, France) were used in all experiments. For intragastric administration, eight animals were fed by delivering to the stomach $10^{12}$ cfu of PEG-purified phage using a blunt steel feeding tube..$^{45}$ Mice received two gavages on day 0 and one at days 7,14 , and 21 . Blood samples were collected by retroorbital puncture 
before each immunization. For intraperitoneal administration, $10^{11} \mathrm{cfu} \mathrm{CsCl}$-purified ${ }^{46}$ phage that had been dialyzed against PBS at $4^{\circ} \mathrm{C}$ were emulsified with complete Freund adjuvant (CFA) for the first immunization (week 0) or with incomplete Freund adjuvant (IFA) (boosting, weeks 3 and 6). For conjugation to keyhole limpet hemocyanin (KLH), an additional cysteine residue was added when necessary to the C-terminal end of the peptide. Peptides were then bound to maleimide- KLH (Maleimide- activated KLH Conjugation Kit, Sigma) and purified using gel filtration. Mice were immunized with $50 \mu \mathrm{g}$ of protein in either CFA or IFA. Blood samples were collected both before and 10 days after each injection and serum was harvested by centrifugation and stored at $-20^{\circ} \mathrm{C}$. Sera from immunized and control animals were subjected to ELISA. Serum dilutions in PBSM were incubated $1 \mathrm{hr}$ at $37^{\circ} \mathrm{C}$ in 96 -well plates previously coated with $40 \mu \mathrm{l} /$ well of a $3 \mu \mathrm{g} / \mathrm{ml}$ solution of target proteins [gp160, gp120, ferritin, KLH, bovine serum albumin (BSA)]. After washing, bound IgG were revealed with 1/5000 horse- radish peroxidase (HRP)conjugated anti-mouse IgG (Sigma).

\section{Antibody library construction}

Total RNA was extracted ${ }^{47}$ from $10^{8}$ splenocytes obtained from three mice that had been immunized with 3e5. RNA was reverse transcribed using the Stratagene single-strand synthesis kit according to the manufacturer's instructions. Oligonucleotides (purchased from Eurogentec, Ougree, Belgium) used for library construction are listed in Table 1. Single-chain variable fragments ( $\mathrm{ScFvs}$ ) were constructed from rescued genes, essentially as described previously. ${ }^{48}$ Gene segments encoding the variable domains of the heavy (VH) and of the light chain (Vk) antibodies were amplified separately $\left(94^{\circ} \mathrm{C} 40 \mathrm{sec}, 55^{\circ} \mathrm{C} 50 \mathrm{sec}\right.$, $72^{\circ} \mathrm{C} 2 \mathrm{~min} 30$ times, then $3 \mathrm{~min}$ at $72^{\circ} \mathrm{C}$ ) using first round polymerase chain reaction (PCR) primers, ${ }^{49,50}$ and subsequently ligated together by addition of a gene segment encoding a 15mer amino acid linker (G4S)3. To this end, first round PCR products were purified (PCR purification kit, Qiagen) and reamplified to append DNA sequences encoding portions of 
the linker at the $3^{\prime}$ end of the VH and the $5^{\prime}$ end of the VL genes using JH-link: and VKlink primers together with previously used VHMLn and C kappa primers. VH and Vk segments were then assembled in an overlap extension reaction $\left(10\right.$ cycles at $95^{\circ} \mathrm{C} 2 \mathrm{~min}$, $55^{\circ} \mathrm{C} 1 \mathrm{~min}$, and $72^{\circ} \mathrm{C} 3 \mathrm{~min}$ ) using third round PCR primers encoding appropriate restriction sites for cloning into $\mathrm{pHEN}^{43}$ (Table 1). ScFv gene repertoires were transfected in E. coli and rescued as phagemid particles as previously described. ${ }^{48}$ For selection of gp160-specific antibodies, $10^{10} \mathrm{cfu}$ of input phage were incubated for $4 \mathrm{hr}$ at room temperature in 5-ml polystyrene tubes (Becton Dickinson) previously coated overnight with a $2 \mathrm{ml}$ solution of $25 \mu \mathrm{g} / \mathrm{ml}$ of HIV-l gp 160 . Washing steps and rescue of eluted phage were performed as described. ${ }^{48}$ After three rounds of biopanning, individual clones were tested by phage ELISA (described above).

\section{RESULTS}

\section{Selection of IgGI bI2-specific phage mimotopes}

After biopanning using IgGl b12, 54 clones from the pIII library were individually amplified and tested by phage ELISA. All of these clones (Table 2) bind IgGl b12, but do not bind irrelevant proteins (BSA, hemocyanin, and ferritin) or control Abs (IgG1k, an isotype-matched human control antibody of unknown specificity, and F105, a human antibody specific for a gp120 epitope that overlaps the CD4bs but distinct from the IgG1 b12 epitope $e^{40,51}$ ). Figure 1 shows binding analysis of two representative phage clones. Alignment of the sequences of IgG1 b12-specific phage clones enabled us to define an initial consensus sequence $\mathrm{M} / \mathrm{V} \Theta \mathrm{SD}$, where $\Theta$ represents an aromatic amino acid (Table 2). This motif is also present in a previously reported IgGl b12-specific peptide. ${ }^{23}$ To refine the consensus sequence for binding to IgGl b12, we chose to conduct further investigations based on the overrepresented clone 3e5 (LGPVWSDLTC, 22 of 54 clones, Table 2). 
To evaluate the contribution made by each residue in the $3 \mathrm{e} 5$ sequence (Table 2) toward IgG1 b12 binding, we constructed a panel of individual phage clones bearing single alanine substitutions at each position in the mimotope sequence. The capacity of these $3 \mathrm{e} 5$ mutants to bind to IgGl b12 was compared to that of unmodified $3 \mathrm{e} 5$ phage ELISA. While substitution of amino acids in the initial consensus sequence resulted in a dramatie reduction of specific interaction with IgGl b12, substitution of residues outside this region had less impact, particularly at positions N-terminal to the consensus sequence (Fig. 2).

\section{Molecular evolution of IgG1 bI2 mimotopes}

In an attempt to select structures with improved IgG1 b12 binding capacity, we undertook the construction of a second- generation library (L2), in which the consensus sequence M/VWSD was fixed at positions $4,5,6$, and 7, and diversity was introduced into the flanking regions (Table 3). Biopanning of this library led to the selection of two dominant sequences, VLMVWSDEKG and CLLVWSDEAL. After biopanning, ${ }^{32}$ clones were picked at random for sequence analysis (Table 3). Comparison of these sequences suggests that a small or hydrophobic residue (preferably leucine) is best accommodated at position 2, while a valine is preferred at position 4 and a glutamic acid at position 8 . Based on this information, a third-generation library (L3: XLXVWXDEXX) was designed. We chose to randomize position 6 in this library to verify the importance of serine in the initial consensus sequence, $\mathrm{M} / \mathrm{V \Theta SD}$, since serine was abundant (27 clones out of 54) but not ubiquitous at this position after selection of the initial library. Most clones selected from this third library included glycine or serine at the first position and a hydrophobic residue (usually leucine or methionine) at position 3. Histidine and leucine were similarly abundant (9 of 28 and 10 of 28 , respectively) at position 9 . The data also confirm that serine is indeed favored at position 6 (Table 3). We therefore identified G/SLL/MVWSDEL/H as a refined consensus sequence for binding to IgGl b12 (Table 3), and we opted to carry out further studies using clones $3 \mathrm{e} 5,3 \mathrm{r}$, and 19 as representatives from selection on the starting library, L2 and L3, 
respectively. We first compared by ELISA the binding of these first-, second-, and thirdgeneration phage mimotopes to IgG1 b12 (Fig. 3). It would appear from these results that the $3 \mathrm{r} 9$ and 19 phage mimotopes (second and third generation, respectively) have a higher affinity for IgG1 b12 than 3e5 (first generation).

\section{Phage peptides and gp160 compete for binding to IgG1 b12}

As expected, increasing concentrations of gp120 $(1-10 \mu \mathrm{g} / \mathrm{ml})$ inhibited the binding of

phage-displayed mimotopes to IgG1 b12 (Fig. 4) while KLH (used as an irrelevant control) had no effect. These results indicate that the selected phage-displayed peptides bind to IgG1 b12, mimicking the structure of the IgG1 b12 epitope on gp120. On the other hand, we did not detect specific inhibition of the interaction of IgGl b12 with HIV-1 gp160 by the corresponding free peptides, which were also inactive in an envelope-dependent cell fusion $\operatorname{assay}^{52}$ (data not shown).

\section{Selected phage mimotopes are weakly immunogenic}

KLH-peptide conjugates elicited a strong anti- KLH response but did not elicit any gp160specific antibodies in vivo (data not shown). We therefore focused on the immunogenic potential of phage mimotopes. Anti-HIV-1 gp160 IgG or IgA were not detected in the sera of mice subjected to intragastric administration of phage (not shown). Mice were subjected to three intraperitoneal injections with phage peptides 3e5, 3r9, and 19 at three weekly intervals. Sera were collected every 10 days and tested by ELISA for the presence of antiphage and anti-HIV-1 gp160 antibodies. At the end of the immunization schedule, all animals had raised substantial amounts of anti-phage antibodies, with end point titers reaching at least $10^{4}$ (data not shown). Notably, anti-gp160 antibodies were also detected in most vaccinated animals, with ELISA signals at least 4-fold higher on gp160 than on BSA (Figs. 5 and 6). Stronger ELISA signals were seen with the second- and thirdgeneration phage peptides, $3 \mathrm{r} 9$ and 19 , than with $3 \mathrm{e} 5$, the phage peptide clone isolated from 
the initial library (Fig. 6). Typically, anti-gp160 antibodies were detected 11 days after the first injection; serum titers peaked at day 31 , declined thereafter, and became undetectable after 60 days of follow-up (Fig. 5A). As expected, immunization with control phage HA 1.1 elicited an anti-phage response, but anti-gp160 antibodies were not elicited (Fig. 6). The anti-gp160 response elicited by the phage peptides appears to be of broad selectivity, since sera of immunized mice were reactive against envelope from at least five different, unrelated strains of HIV-1 viruses: HIV-1SF2 gp120, HIV-1MN gp120, HIV-1CM gp120, HIV-1IIIB (LAV) gp120, and HIV-1MN gp160 MN (Fig. 5B). Despite the presence of antigp160 antibodies in the immune sera, we were unable to detect neutralizing activity on HIV-1 TCLA (data not shown).

IgG1 b12-like antibody recovered from a phage display library

To further characterize the anti-gp160 antibody response elicited by the phage peptides, we set out to rescue the $\mathrm{VH}$ and VL genes from three mice immunized with the $3 \mathrm{e} 5$ phage and clone them for phage display. The complexity of the resulting ScFv library was estimated to be at least $2 \times 10^{5}$ different clones. After three rounds of biopanning, phage clones were amplified from single colonies picked at random. The amplified phage were then tested by phage ELISA. Clones were considered HIV specific when their phage ELISA reactivity on gp160 MN was at least 5-fold higher than the background signal with BSA in three separate experiments. Only one such clone (phage ScFv5) was identified. A titration assay suggests that ScFv5 has a significantly lower affinity than ScFvb12 for gp160 (Fig. 7). Sequence analysis of phage ScFv5 revealed that the VH and VL CDR3 sequences (GSLDY and QQSNEDPYT, respectively) do not bear any clear homology with the corresponding regions of IgGl b12.53

Assuming that ScFv5 was elicited in response to immunization with an IgG1 b12 mimotope, we set out to ascertain whether ScFv5 recognizes the same epitope as IgGl b12, by measuring inhibition of binding of the phage ScFv to gp160 by IgGl b12. We found that 
gp160 binding of phage ScFv5 and phage ScFvb12, a phage clone expressing the VH and VL genes of IgGl b12 in ScFv format, ${ }^{54}$ was inhibited to a similar extent by IgG 1 b12 (Fig. 8). Hence it is likely that ScFv5 recognizes an epitope similar to that of IgGl b12.

\section{DISCUSSION}

Here we report the use of a phage display approach to identify mimotopes of the neutralizing anti-gp160 antibody $\operatorname{IgG} 1 \mathrm{~b} 12,{ }^{24,25}$ and we explore their potential for use as phage peptide vaccines.

Panning a phage peptide library on immobilized IgGl b12 revealed a strong four-residue consensus motif MN@SD (where $\Theta$ represents an aromatic residue, preferably W) (Table 2), and the importance of each residue in the motif was confirmed using an alanine-scanning approach (Fig. 2). Interestingly, a previously described peptide that specifically binds IgG1 b12, B2.1 (HERSYMFSDLENRCI), ${ }^{23}$ which was selected from a phage peptide library displayed on pVIII, also contains the four-residue motif (bold letters). In this study, the authors emphasized the importance of an unpaired cysteine residue for binding activity, showing that it enabled the formation of IgG1 b12-binding peptide homodimers to be presented on the phage coat protein via a disulfide bond. Some of the IgG1 b12-specific mimotopes described in our study (including 3e5) include an unpaired cysteine residue, but since this is not a constant feature of all specific clones, we would suggest that the formation of homodimers is not essential for the binding activity of the phage mimotopes.

To extend and refine the consensus sequence, we constructed second- and third-generation libraries (L2 and L3), in which the amino acids identified in earlier selection experiments were fixed, and diversity was introduced into flanking positions. Analysis of selected sequences from L2 and L3 libraries led us to identify a refined, nine-residue consensus sequence, G/SLL/MVWSDEL/H.

Representative clones selected from first-, second-, and third- generation libraries were then compared in terms of immunogenicity. We show in Figure 6 that mice vaccinated with 
clone 19 (third generation) exhibited on average a stronger gp160-specific antibody response than mice vaccinated with $3 \mathrm{e} 5$ (first generation) or 3r9 (second generation). It should be noted, however, that increased immunogenecity is not necessarily a direct reflection of increased binding affinity for IgGl b12. It could equally relate to more efficient expression on the surface of phage, i.e., more copies of pIII-peptide fusions per phage particle.

While we were able to detect competition between phage peptides and soluble gp160 for binding to IgG1 b12, the free, soluble peptide mimotopes were unable to compete efficiently with gp160 or phage-borne peptide for binding to IgG1 b12 (data not shown), and they were inactive at blocking envelope-mediated cell fusion when tested up to high micromolar concentrations (data not shown). Together, these results suggest that the environment in which the peptide is presented may have a major impact on its ability to bind IgG1 b12. Binding of unconstrained peptides with their targets invariably leads to entropic loss, which will lower the binding affinity compared to that of the same peptide that is constrained in a binding conformation. ${ }^{55}$ It is plausible that the peptides were presented in a constrained form, owing to interactions with $\mathrm{pIII}$, and that the phage clones that were selected during biopanning displayed peptides that were constrained into an IgG1 b12-binding conformation, thereby enhancing interaction with the antibody. It was shown that a phage-displayed peptide corresponding to the V3 loop of HIV-1 binds anti-V3 loop antibodies and adopts a conformation similar to the antibody-bound free peptide. ${ }^{56}$ If $\mathrm{pIII}$ did play an important role in the presentation of mimotope peptides in a binding conformation, it could be predicted that only pIII-fused mimotopes would efficiently induce cognate antibodies in vivo. This hypothesis is supported by our observation that while immunization with phage peptide mimotopes elicited gp160-specific antibodies, immunization with peptide mimotopes conjugated to KLH did not. Therefore, it is possible that structural constraints imposed by the phage coat play an important role in the 
immunogenicity of the selected peptide, and that the phage particle, or at least the pIII protein, should be considered an important element in vaccine formulation.

In contrast to mice immunized with the $\mathrm{B} 2.1$ mimotope peptide, ${ }^{23}$ mice vaccinated with IgG1 b12 phage mimotopes 3e5, 3r9, or 19 clearly mounted an HIV-specific humoral response (Figs. 5 and 6). No experimental data or details of the immunization procedure are provided in the article by Zwick et al. ${ }^{23}$ and it is possible that differences in the immunization protocol used (phage titer, type of adjuvant) could account for the lack of B2.1-induced antibodies cross-reactive to gp120.

In an attempt to characterize the anti-gp160 antibodies in the immune sera from 3e5vaccinated mice, we attempted to rescue anti-gp160 antibodies by phage display. We identified one phage antibody clone (ScFv5) that shares a common epitope with IgG1 b12 on gp120 (Fig. 8). This result provides further confirmation that immunization with phage mimotopes elicits the production of antibodies with IgGl b12-like specificity.

Despite the presence of anti-gp160 immunoreactivity, the immune sera from the immunized mice did not neutralize laboratory-adapted strains of HIV in vitro (data not shown). This could be explained, at least in part, by the relatively low titer of gp160 cross-reactive antibodies in the sera (Figs. 5 and 6). Another potential explanation would be that as previously emphasized, ${ }^{23}$ 18-residue CDRH3 loops, such as the one borne by IgGl b12, are not produced in mice. ${ }^{57}$ Therefore, it is plausible that only low-affinity antibodies could be raised in mice against that particular epitope. In any case, our results presented in Figure 7 suggest that ScFv5 has a significantly lower affinity than ScFvb12 for gp160.

The problem of low titer could be addressed by vaccine formulation. A notable consequence of the low number of copies (3-5) of pIII per phage particle is that the amount of phagedisplayed peptide that can be injected into an animal is limited, for example, a large dose of phage ( $10^{14}$ particles) would represent, at best, a few nanomoles of peptide. A potential solution would be to use purified preparations of peptide fused to soluble variants of pIII protein $^{58}$ instead of phage. Such an approach would enable the dose of peptide injected to 
be significantly increased while retaining what we suspect is an essential constrained conformation imposed by the phage protein. The issue of CDRH3 loop length would need to be addressed by vaccination experiments in nonhuman primates, which would be more likely to raise an immune response including antibodies bearing long CDRH3 loops. Of note, protective immune responses have been successfully induced in macaques vaccinated with phage-displayed HIV-l epitopes. ${ }^{59}$ It would be interesting to test mimotopes of a highly neutralizing epitope such as the one recognized by IgGl b12 in such a setting.

\section{ACKNOWLEDGMENTS}

This study was supported by the Swiss National Science Foundation (Project 3339-6203200), Agence Nationale de la Recherche contre le SIDA (ANRS, Paris), INSERM, and Assistance Publique-Hopitaux de Paris.

\section{REFERENCES}

1. Willey RL, Bonifacino JS, Potts BJ, Martin MA, and Klausner RD: Biosynthesis, cleavage, and degradation of the human immunodeficiency virus 1 envelope glycoprotein gp160. Proc Natl Acad Sei USA 1988;85:9580-9584.

2. Nara PL, Garrity RR, and Goudsmit J: Neutralization of mV-1: A paradox of humoral proportions. FASEB J 1991;5:2437-2455.

3. Haynes BF, Pantaleo G, and Fauci AS: Toward an understanding of the correlates of protective immunity to $\mathrm{mv}$ infection. Science 1996;271:324-328.

4. Moog C, Fleury HJ, Pellegrin I, Kim A, and Aubertin AM: Autologous and heterologous neutralizing antibody responses following initial seroconversion in human immunodeficiency virus type 1-infected individuals. J Virol 1997;71:3734-3741.

5. Letvin NL: Progress in the development of an $\mathrm{mV}-1$ vaccine. Science 1998;280:1875-1880. 
6. Weiss RA, Clapham PR, Weber JN, Dalgleish AG, Lasky LA, and Berman PW: Variable and conserved neutralization antigens of hu- man immunodeficiency virus. Nature 1986;324:572-575.

7. Robert-Guroff M, Goedert Il, Naugle CJ, Jennings AM, Blattner W A, and Gallo RC: Spectrum of mv -1 neutralizing antibodies in a cohort of homosexual men: Results of a 6 year prospective study. AIDS Res Hum Retroviruses 1988;4:343-350.

8. Connor RI, Korber BT, Graham BS, Hahn BH, Ho DD, Walker BD, Neumann AU, Vermund SH, Mestecky J, Jackson S, Fenamore E, Cao Y, Gao F, Kalams S, Kunstman KJ, McDonald D, McWilliams N, Trkola A, Moore JP, and Wolinsky SM: Immunological and virological analyses of persons infected by human immunodeficiency virus type 1 while participating in trials of recombinant gp120 subunit vaccines. J Virol 1998;72:1552-1576.

9. D'Souza MP, Geyer SJ, Hanson CV, Hendry RM, and Milman G: Evaluation of monoclonal antibodies to $\mathrm{mV}-1$ envelope by neutralization and binding assays: An international collaboration. AIDS 1994;8:169-181.

10. D'Souza MP, Milman G, Bradac JA, McPhee D, Hanson CV, and Hendry RM: Neutralization of primary HIV-1 isolates by anti-envelope monoclonal antibodies. AIDS 1995;9:867-874.

11. Valenzuela A, Blanco J, Krust B, Franco R, and Hovanessian AG: Neutralizing antibodies against the V3 loop of human immunodeficiency virus type 1 gp120 block the CD4-dependent and -independent binding of virus to cells. J ViroI1997;71:8289-8298.

12. Schreiber M, Wachsmuth C, Muller H, Odemuyiwa S, Schrnitz H, Meyer S, Meyer $\mathrm{B}$, and Schneider-Mergener $\mathrm{J}$ : The $\mathrm{V} 3$-directed immune response in natural human immunodeficiency virus type 1 infection is predominantly directed against a variable, discontinuous epitope presented by the gp120 V3 domain. J Virol 1997; 71 :9198-9205.

13. Polzer S, Dittrnar MT, Schmitz H, and Schreiber M: The N-linked glycan g15 within the V3 loop of the HIV-1 external glycoprotein gp120 affects coreceptor usage, cellular tropism, and neutralization. Virology 2002;304:70-80. 
14. Kwong PD, Doyle ML, Casper DJ, Cicala C, Leavitt SA, Majeed S, Steenbeke TD, Venturi M, Chaiken I, Fung M, Katinger H, Par- ren PW, Robinson J, Van Ryk D, Wang L, Burton DR, Freire E, WyattR, Sodroski J, Hendrickson WA, and Arthos J: HIV-1 evades antibody-mediated neutralization through conformational masking of receptor-binding sites. Nature 2002;420:678-682.

15. Wyatt R, Kwong PD, Desjardins E, Sweet RW, Robinson J, Hendrickson W A, and Sodroski JG: The antigenic structure of the mv gp120 envelope glycoprotein. Nature 1998;393:705-711.

16. Poignard P, KIasse PJ, and Sattentau QJ: Antibody neutralization of HIV-1. Immunol Today 1996;17:239-246.

17. Parren PW, Burton DR, and Sattentau QJ: HIV-1 antibody-debris or virion? Nat Med 1997;3:366-367.

18. Burton DR: A vaccine for mv type 1: The antibody perspective. Proc Natl Acad Sci USA 1997;94:10018-10023.

19. Pantophlet R, OIlrnann Saphire E, Poignard P, Parren PW, Wilson IA, and Burton DR: Fine mapping of the interaction of neutralizing and nonneutralizing monoclonal antibodies with the CD4 binding site of human immunodeficiency virus type 1 gp120. J Virol 2003;77:642-658.

20. Saphire EO, Parren PW, Pantophlet R, Zwick MB, Morris GM, Rudd PM, Dwek RA, Stanfield RL, Burton DR, and Wilson IA: Crystal structure of a neutralizing human IGG against HIV-1: A template for vaccine design. Science 2001;293:1155-1159.

21. Zwick MB, Parren PW, Saphire EO, Church S, Wang M, Scott JK, Dawson PE, Wilson IA, and Burton DR: Molecular features of the broadly neutralizing immunoglobulin G1 b12 required for recognition of human immunodeficiency virus type 1 gp120. J Virol 2003;77:5863-5876.

22. Boots U, McKenna PM, Arnold BA, Keller PM, Gorny MK, Zolla-Pazner S, Robinson JE, and Conley Al: Anti-human immunodeficiency virus type 1 human 
monoclonal antibodies that bind discontinuous epitopes in the viral glycoproteins can identify mimotopes from recombinant phage peptide display libraries. AIDS Res Hum Retroviruses 1997;13:1549-1559.

23. Zwick MB, Bonnycastle LL, Menendez A, Irving MB, Barbas CF, 3rd, Parren PW, Burton DR, and Scott JK: Identification and characterization of a peptide that specifically binds the human, broadly neutralizing anti-human immunodeficiency virus type 1 antibody b12. J ViroI 2001;75:6692-6699.

24. Burton DR, Barbas CF, 3rd, Persson MA, Koenig S, Chanock RM, and Lerner RA: A large array of human monoclonal antibodies to type 1 human immunodeficiency virus from combinatorial libraries of asymptomatic seropositive individuals. Proc Natl Acad Sei USA 1991 ;88: 10134-10137.

25. Burton DR, Pyati J, Koduri R, Sharp SJ, Thornton GB, Parren PW, Sawyer LS, Hendry RM, Dunlop N, Nara PL, et al.: Efficient neutralization of primary isolates of mv 1 by a recombinant human monoclonal antibody. Science 1994;266:1024-1027.

26. Trkola A, Purtscher M, Muster T, Ballaun C, Buchacher A, Sullivan N, Srinivasan K, Sodroski J, Moore JP, and Katinger H: Human monoclonal antibody 2G12 defines a distinctive neutralization epitope on the gp120 glycoprotein of human immunodeficiency virus type 1. J Virol 1996;70:1100-1108.

27. Sanders RW, Venturi M, Schiffuer L, Kalyanararnan R, Katinger H, Lloyd KO, Kwong PD, and Moore JP: The mannose-dependent epitope for neutralizing antibody 2G12 on human immunodeficiency virus type 1 glycoprotein gp120. J Virol 2002;76:7293-7305. 28. ScanIan CN, Pantophlet R, Wormald MR, Ollmann Saphire E, Stanfield R, Wilson 1A, Katinger H, Dwek RA, Rudd PM, and Bur- ton DR: The broadly neutralizing antihuman immunodeficiency virus type 1 antibody $2 \mathrm{G} 12$ recognizes a cluster of alpha1-2 mannose residues on the outer face of gp120. J Virol 2002; 76:7306-7321.

29. Moulard M, Phogat SK, Shu Y, Labrijn AF, Xiao X, Binley JM, Zhang MY, Sidorov IA, Broder CC, Robinson J, Parren PW, Bur- ton DR, and Dimitrov DS: Broadly cross- 
reactive HIV-1-neutralizing human monoclonal Fab selected for binding to gp120-CD4CCR5 complexes. Proc Natl Acad Sci USA 2002;99:6913-6918.

30. Stiegler G, Kunert R, Purtscher M, Wolbank S, Voglauer R, Steindl F, and Katinger $\mathrm{H}$ : A potent cross-clade neutralizing human monoclonal antibody against a novel epitope on gp41 of human immunodeficiency virus type 1. AIDS Res Hum Retroviruses 2001; 17:1757-1765.

31. Muster T, Steindl F, Purtscher M, Trkola A, KIirna A, Himmler G, Ruker F, and Katinger H: A conserved neutralizing epitope on gp41 of human immunodeficiency virus type 1. J ViroI1993;67:6642-6647.

32. Conley A1, Kessler JA 2nd, Boots U, Tung JS, Arnold BA, Keller PM, Shaw AR, and Emini EA: Neutralization of divergent human immunodeficiency virus type 1 variants and primary isolates by IAM-41-2F5, an anti-gp41 human monoclonal antibody. Proc Natl Acad Sci USA 1994;91:3348-3352.

33. Zwick MB, Wang M, Poignard P, Stiegler G, Katinger H, Burton DR, and Parren PW: Neutralization synergy of human immunodeficiency virus type 1 primary isolates by cocktails of broadly neutralizing antibodies. J Virol 2001;75:12198-12208.

34. Parren PW, Ditzel Hl, Gulizia RJ, Binley JM, Barbas CF 3rd, Bur- ton DR, and Mosier DE: Protection against HIV-1 infection in hu-PBL-SCID mice by passive immunization with a neutralizing human monoclonal antibody against the gp120 CD4binding site. AIDS 1995;9:F1-6.

35. Gauduin MC, Parren PW, Weir R, Barbas CF, Burton DR, and Koup RA: Passive immunization with a human monoclonal antibody protects hu-PBL-SCID mice against challenge by primary isolates of HIV-1. Nat Med 1997;3:1389-1393.

36. Parren PW, Marx PA, Hessell Al, Luckay A, Harouse J, Cheng- Mayer C, Moore JP, and Burton DR: Antibody protects macaques against vaginal challenge with a pathogenic R5 simian/human immunodeficiency virus at serum levels giving complete neutralization in vitro. J ViroI2oo1;75:8340-8347. 
37. Mascola JR, Lewis MG, Stiegler G, Harris D, VanCott TC, Hayes D, Louder MK, Brown CR, Sapan CV, Frankel SS, Lu Y, Robb ML, Katinger H, and Birx DL: Protection of macaques against pathogenic simian/human immunodeficiency virus 89.6PD by passive transfer of neutralizing antibodies. J ViroI1999;73:40o9-4018.

38. Mascola JR, Stiegler G, VanCott TC, Katinger H, Carpenter CB, Hanson CE, Beary H, Hayes D, Frankel SS, Birx DL, and Lewis MG: Protection of macaques against vaginal transmission of a pathogenic HIV-1/SIV chimeric virus by passive infusion of neutralizing antibodies. Nat Med 2000;6:207-210.

39. Hofmann-Lehmann R, Vlasak J, Rasmussen RA, Smith BA, Baba TW, Liska V, Ferrantelli F, Montefiori DC, McClure HM, Ander- son DC, Bernacky BJ, Rizvi TA, Schmidt R, Hill LR, Keeling ME, Katinger H, Stiegler G, Cavacini LA, Posner MR, Chou TC, Andersen J, and Ruprecht RM: Postnatal passive immunization of neonatal macaques with a triple combination of human monoclonal antibodies against oral simian-human immunodeficiency virus challenge. J Virol 2001;75:7470-7480.

40. Posner MR, Hideshima T, Cannon T, Mukherjee M, Mayer KU, and Byrn RA: An IgG human monoclonal antibody that reacts with HIV-1/GP120, inhibits virus binding to cells, and neutralizes infection. J Immunol 1991;146:4325-4332.

41. Fisch I, Kontermann RE, Finnem R, Hartley 0, Soler-Gonzalez AS, Griffiths AD, and Winter G: A strategy of exon shuffling for making large peptide repertoires displayed on filamentous bacteriophage. Proc Natl Acad Sei USA 1996;93:7761-7766.

42. Houimel M, Mach JP, Corthesy-Theulaz I, Corthesy B, and Fisch 1: New inhibitors of Helicobacter pylori urease holoenzyme selected from phage-displayed peptide libraries. Eur J Biochem 1999;262:774-780.

43. Hoogenboom UR, Griffiths AD, Johnson KS, Chiswell DJ, Hud- son P, and Winter G: Multi-subunit proteins on the surface of filamentous phage: Methodologies for displaying antibody (Fab) heavy and light chains. Nucleic Acids Res 1991;19:4133-4137. 
44. McCafferty J, Griffiths AD, Winter G, and Chiswell DJ: Phage antibodies: Filamentous phage displaying antibody variable domains. Nature 1990;348:552-554.

45. Delmastro P, Meola A, Monaci P, Cortese R, and Galfre G: 1mmunogenicity of filamentous phage displaying peptide mimotopes after oral administration. Vaccine 1997; 15:1276-1285.

46. Smith GP and Scott JK: Libraries of peptides and proteins displayed on filamentous phage. Methods EnzymoI1993;217:228-257.

47. Chomczynski P and Sacchi N: Single-step method of RNA isolation by acid guanidinium thiocyanate-phenol-chloroform extraction. Anal Biochem 1987;162:156-159. 48. Marks JD, Hoogenboom UR, Bonnert TP, McCafferty J, Griffiths AD, and Winter G: By-passing immunization. Human antibodies from V-gene libraries displayed on phage. J Mol Biol 1991;222: 581-597.

49. Dattamajumdar AK, Jacobson DP, Hood LE, and Osman GE: Rapid cloning of any rearranged mouse immunoglobulin variable genes. Immunogenetics 1996;43:141-151.

50. Jones ST and Bendig MM: Rapid PCR-cloning of full-length mouse immunoglobulin variable regions. Biotechnology (NY) 1991;9:579.

51. Posner MR, Cavacini LA, Ernes CL, Power J, and Byrn R: Neutralization of HIV-I by F105, a human monoclonal antibody to the CD4 binding site of gp120. J Acquir Immune Defic Syndr 1993; 6:7-14.

52. Dragic T, Hazan U, and Alizon M: In: Methods in Molecular Genetics. Academic Press, San Diego, CA, 1995, pp. 218-236.

53. Barbas CF 3rd, Collet TA, Amberg W, Roben P, Binley JM, Hoekstra D, Cababa D, Jones TM, Williamson RA, Pilkington GR, et al.: Molecular profile of an antibody response to HIV-1 as probed by combinatorial libraries. J Mol Biol 1993;230:812-823.

54. Bitton N, Verrier F, Debre P, and Gorochov G: Characterization of T cell-expressed chimeric receptors with antibody-type specificity for the CD4 binding site of HIV-1 gp120. Eur J Immunol 1998;28:4177-4187. 
55. O'Neil KT, Hoess RH, Jackson SA, Ramachandran NS, Mousa SA, and DeGrado WF: Identification of novel peptide antagonists for GPIIb/IIIa from a conformationally constrained phage peptide library. Proteins 1992;14:509-515.

56. Jelinek R, Terry TD, Gesell J], Malik P, Perham RN, and Opella SJ: NMR structure of the principal neutralizing determinant of HIV-1 displayed in filamentous bacteriophage coat protein. J Mol Biol 1997;266:649-655.

57. Mian IS, Bradwell AR, and Olson Al: Structure, function and prop- erties of antibody binding sites. J Mol Biol 1991;217:133-151.

58. Mersmann M, Schmidt A, Tesar M, Schoneberg A, Welschof M, Kipriyanov S, Temess P, Little M, Pfizenmaier K, and Moosmayer D: Monitoring of scFv selected by phage display using detection of scFv-pIll fusion proteins in a microtiter scale assay. $\mathrm{J}$ Immunol Methods 1998;220:51-58.

59. Chen X, Scala G, Quinto r, Liu W, Chun TW, Justement JS, Co- hen OJ, vanCott TC, Iwanicki M, Lewis MG, Greenhouse J, Barry T, Venzon D, and Fauci AS: Protection of rhesus macaques against disease progression from pathogenic SHIV-89.6PD by vaccination with phage-displayed HIV-1 epitopes. Nat Med 2001;7:1225-1231. 


\section{FIGURE LEGENDS}

FIG. 1. Analysis of binding of IgGl b12-selected clones by phage ELISA. (A) Binding to indicated (box) plate-adsorbed antibodies. (B) Binding to plate-adsorbed IgGl b12 and indicated irrelevant proteins (box). In each case (A,B) one representative experiment out of five performed is presented.

FIG. 2. IgGl b12-binding abilities of $3 \mathrm{e} 5$ mutants. Phage clones bearing the indicated mutant peptides were tested by ELISA for their abilities to bind plate-adsorbed IgGl b12. Maximal effect on binding is seen when the substitutions affect a residue in the VWSD motif.

FIG. 3. Comparison of the capacity of first-, second-, and third-generation phage mimotopes ( $3 \mathrm{e} 5,3 \mathrm{r}$, and 19 , respectively) to bind to IgGl b12. Phage clones bearing the indicated peptides were tested by ELISA for their abilities to bind plate-adsorbed IgGl b12. PhageHA is a negative control that does not bind IgGl b12.

FIG. 4. Competition for phage binding to immobilized IgG1 b12 by in-solution gp120 (1 $\mu \mathrm{g}, 5 \mu \mathrm{g}, 10 \mu \mathrm{g}$, as indicated) or $10 \mu \mathrm{g} / \mathrm{ml}$ of control $\mathrm{KLH}$ is shown. A greater than $70 \%$ decrease in binding is obtained using the highest concentration of gp120. Data shown are from one of three separate experiments, which gave similar results.

FIG. 5. Antibody response induced by vaccinations with phage 3e5. (A) Serum reactivity (dilution 1/100) of three different mice $(1,2,3)$ to plate-adsorbed HIV-1 MN gp160 and irrelevant proteins was assayed in ELISA. (B) Serum Abs from animal number 4 were tested for binding to gp120 from four different HIV-1 strains (as indicated) by ELISA. 
FIG. 6. Groups of mice were injected with the indicated phage clone mimotopes or control phage displaying the HA 1.1 peptide. Serum reactivities with immobilized BSA (open circles) or gp160 (closed circles) were assayed in ELISA at day 21 after the first injection. Phage displaying the HA peptide was used as control. The number of mice injected in each group is indicated in parentheses. A $3 \mu \mathrm{g} / \mathrm{ml}$ solution of target proteins (gp160 or BSA) was used to coat the plates.

FIG. 7. Analysis by phage ELISA of binding of phage ScFv5, rescued from mice immunized with the $3 \mathrm{e} 5 \mathrm{IgGl}$ b12 mimotope, phage ScFv-b12, and irrelevant control phage ScFv-OKT3 to plate adsorbed gp160.

FIG. 8. Phage ScFv5 has a similar binding specificity to phage ScFv-b12 itself. Competition for phage ScFv binding to immobilized gp160 by soluble IgGl b12 (gray boxes) or control IgG1k (black boxes). No binding was observed to plate adsorbed with control protein KLH (open boxes). Phage HA 1.1 was used as an irrelevant control. Data shown are from one of three separate experiments, which gave similar results. 


\section{TABLES}

Table 1. Oligonucleotides used in construction of murine ScFv library

Round 1
VHML1
VHML2
VHML3
VHML4
VHML5
VHML6
VHML7
VHML8
VHML9
VHML10
VHML11
VHML12
VKML1
VKML2
VKML3
VKML4
VKML5
VKML6
VKML7
VKML8
VKML9
VKML10
VKML11
C $\gamma$

Round 2

JH1m Link JH2m Link JH3m Link JH4m Link VK1 Link VK2 Link VK3 Link VK4 Link VK5 Link

Round 3 VH1 Sfi VH2 Sfi VH3 Sfi VH4 Sfi VH5 Sfi VH6 Sfi CK Not

\begin{abstract}
ATGAAATGCAGCTGGGTCAT ATGGGATGGAGCTRTATCAT TGAAGWTGTGGTTAAACTGG ATGRACTTTGGGYTCCAGCT ATGGACTCCAGGCTCAATTT ATGGCTGTCYTRGSGCTRCT ATGGRATGGAGCKGGATCTT ATGAGAGTGCTGATTCTTTT ATGGMTTGGGTGTGGAMCTG ATGGGCAGACTTACATTCTC ATGGATTTTGGGCTGATTTT ATGATGGTGTTAAGTCTTCT ATGAAGTTGCCTGTTAGGCT ATGGAGWCAGACACACTCCT ATGAGTGTGGCTCATTCAGG ATGAGGRCCCCTGCTCAGWT ATGGATTTWCAGGTGCAGAT ATGAGGTKCCYTGYTCAGYT ATGGGCWTCAAGATGGAGTC ATGTGGGGAYCTTKTTYCMMT ATGGTRTCCWCASCTCAGTT ATGTATATATGTTTGTTGTC ATGGAAGCCCCATGCTCAGC CTCAGGGAARTAGCCYTTGAC
\end{abstract}

\begin{abstract}
CCAGAGCCACCTCCGCCTGAACCGCCTCCACCTGAGGAGACGGTGACCGTGGTCCC CCAGAGCCACCTCCGCCTGAACCGCCTCCACCTGAGGAGACTGTGAGAGTGGTGCC CCAGAGCCACCTCCGCCTGAACCGCCTCCACCTGAGGAGACGGTGACTGAGGTTCC CCAGAGCCACCTCCGCCTGAACCGCCTCCACCTGCAGAGACAGTGACCAGAGTCCC CAGGCGGAGGTGGCTCTGGAGGTGGCGGATCGGACATCCAGATGACCCAGTCTCC CAGGCGGAGGTGGCTCTGGAGGTGGCGGATCGGATATTGTGATGACCCAGACTCCAC CAGGCGGAGGTGGCTCTGGAGGTGGCGGATCGGAAATTGTGWTGACRCAGTCTC CAGGCGGAGGTGGCTCTGGAGGTGGCGGATCGGACATCGTGATGACCCAGTCTCC CAGGCGGAGGTGGCTCTGGAGGTGGCGGATCGGAAACGACACTCACGCAGTCTCC

GTCCTCGCAACTGCGGCCCAGCCGGCCATGGCCCAGGTGCAGCTGGTRCARTCTGG GTCCTCGCAACTGCGGCCCAGCCGGCCATGGCCCAGGTCACCTTGARGGAGTCTGG GTCCTCGCAACTGCGGCCCAGCCCGGCCATGGCCGAGGTGCAGCTGGTGGAGTCTGG GTCCTCGCAACTGCGGCCCAGCCGGCCATGGCCCAGGTGCAGCTGCAGSAGTSGGG GTCCTCGCAACTGCGGCCCAGCCGGCCATGGCCCAGGTGCAGCTGGTGCAGTCYGS GTCCTCGCAACTGCGGCCCAGCCGGCCATGGCCCAGGTACAGCTGCAGCAGTCAGG GCTCACTTGGATGGGCGGCCGCTGGATACAGTTGGTGCAGCATC
\end{abstract}




\section{Table 2. Phage clones selected by IgG1 b12}

\begin{tabular}{|c|c|c|c|c|c|}
\hline \multirow{2}{*}{$\begin{array}{l}\text { Library } \\
\text { pIII }\end{array}$} & \multirow[t]{2}{*}{ Clone } & \multirow{2}{*}{ 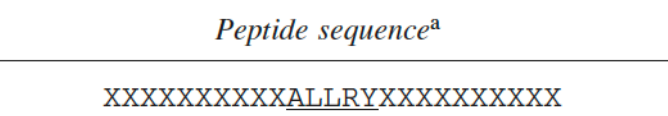 } & \multirow{2}{*}{$\frac{\text { Recovery }}{54^{\mathrm{c}}}$} & \multicolumn{2}{|c|}{ ELISA $^{\mathrm{b}}$} \\
\hline & & & & IgG1 b12 & Control $\mathrm{Ab}$ \\
\hline & $\mathrm{KTa} 2$ & ALLRYTTSNPGLKPS & 1 & 0.575 & 0.010 \\
\hline & KTa12 & FLCKCYTLLEALLRYSLTPWGASPG & 1 & 0.902 & 0.152 \\
\hline & $5 \mathrm{f} 11$ & ALLRYDDPQASP & 1 & 0.575 & 0.102 \\
\hline & $5 \mathrm{a} 2$ & MMHDYFFCGDALLRYDDPQASPV & 9 & 1.290 & 0.215 \\
\hline & $5 b 11$ & MMHDYFFCGDALLRYVPESTRTS & 1 & 0.882 & 0.217 \\
\hline & $5 \mathrm{~b} 8$ & SGRSTWMWSDALLRYVPDRWSPVFV & 1 & 0.973 & 0.026 \\
\hline & $5 \mathrm{~g} 7$ & NFSLMWDDEFALLRYVPESTRTSSP & 14 & 1.756 & 0.030 \\
\hline & $5 \mathrm{~g} 11$ & LKGLQLVYSDALLRY & 2 & 0.946 & 0.276 \\
\hline & $3 e 5$ & ALLRYLGPVWSDLTC & 22 & 0.953 & 0.153 \\
\hline & $2.2 \mathrm{H} 5$ & ALLRYSVPALPFSFP & 1 & 0.850 & 0.145 \\
\hline & $5 c 6$ & ALLRYPPAFSR & 1 & 0.554 & 0.075 \\
\hline Consensus & & $\mathrm{M} / \mathrm{V} \Theta \mathrm{SD}^{\mathrm{d}}$ & & & \\
\hline
\end{tabular}

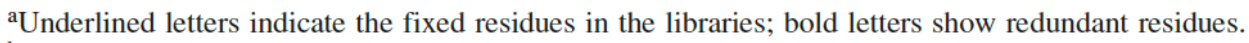

bAbsorbance at (650-450) $\mathrm{nm}$ from ELISA.

${ }^{\mathrm{c} N u m b e r}$ of total clones sequenced in the biopannings.

${ }^{\mathrm{d}} \mathrm{M} / \mathrm{V}, \mathrm{M}$ or $\mathrm{V} ; \boldsymbol{\Theta}$, aromatic residue; $\mathrm{X}$, random residues. 


\section{Table 3. Molecular evolution of IgG1 b12 mimotopes}

\begin{tabular}{|c|c|c|c|c|c|c|c|c|c|c|c|}
\hline \multicolumn{10}{|c|}{ Peptide sequence ${ }^{\mathrm{a}}$} & \multirow{2}{*}{$\begin{array}{r}\text { Clone } \\
\text { (L2) }\end{array}$} & \multirow{2}{*}{$\frac{\text { Recovery }}{32^{\mathrm{b}}}$} \\
\hline$X$ & $\mathrm{X}$ & $\mathrm{X}$ & $\mathrm{M} / \mathrm{V}$ & W & $S$ & D & $\mathrm{X}$ & $\mathbf{x}$ & $\mathbf{X}$ & & \\
\hline V & $\mathbf{L}$ & M & V & . & . & . & $\mathbf{E}$ & $\mathrm{K}$ & G & $3 \mathrm{r} 9$ & 13 \\
\hline $\mathrm{C}$ & $\mathbf{L}$ & $\mathrm{L}$ & V & . & . & . & $\mathbf{E}$ & A & $\mathrm{L}$ & & 4 \\
\hline C & W & & V & & & . & $\mathbf{E}$ & $\mathrm{Y}$ & $\mathrm{N}$ & & 1 \\
\hline E & V & V & V & . & . & . & $\mathrm{F}$ & $\mathrm{Y}$ & Q & & 1 \\
\hline $\mathrm{F}$ & G & M & V & . & . & . & $\mathrm{Y}$ & A & $\mathrm{P}$ & & 1 \\
\hline G & A & V & M & . & . & . & Q & A & $\mathrm{L}$ & & 1 \\
\hline G & $\mathbf{L}$ & $\mathrm{L}$ & M & . & . & . & L & $S$ & $P$ & & 1 \\
\hline $\mathrm{L}$ & D & D & M & . & . & . & $\mathbf{E}$ & $\mathrm{L}$ & $P$ & & 1 \\
\hline $\mathrm{L}$ & G & F & V & . & . & . & G & D & A & & 1 \\
\hline $\mathrm{L}$ & G & $S$ & V & . & . & . & D & $\mathrm{T}$ & $P$ & & 1 \\
\hline $\mathrm{R}$ & G & G & V & . & . & . & $\mathrm{F}$ & A & V & & 1 \\
\hline $\mathrm{R}$ & G & V & M & . & . & . & $S$ & I & $P$ & & 1 \\
\hline $\mathrm{R}$ & I & L & M & . & . & . & $P$ & $\mathrm{~L}$ & $P$ & & 1 \\
\hline S & S & W & M & . & . & . & L & $\mathrm{E}$ & $\mathrm{P}$ & & 1 \\
\hline V & $\mathrm{S}$ & V & V & . & . & . & $P$ & $\mathrm{~T}$ & S & & 1 \\
\hline Y & V & $\mathrm{T}$ & V & & & & E & A & $\mathrm{P}$ & & 1 \\
\hline $\mathrm{X}$ & $\mathrm{L}$ & $\mathrm{X}$ & V & $\dot{\mathrm{W}}$ & $\dot{X}$ & $\dot{\mathrm{D}}$ & $\mathrm{E}$ & $\mathrm{X}$ & $\mathrm{X}$ & (L3) & $28^{\mathrm{b}}$ \\
\hline G & . & M & . & . & $\mathbf{S}$ & . & . & H & G & 19 & 5 \\
\hline $\mathbf{S}$ & . & L & . & . & $\mathbf{S}$ & . & . & L & D & & 3 \\
\hline$S$ & . & $\mathrm{L}$ & . & . & $\mathbf{S}$ & . & . & H & C & & 3 \\
\hline G & . & M & . & . & $\mathbf{S}$ & . & . & L & G & & 2 \\
\hline S & . & L & . & . & $\mathbf{S}$ & . & . & $\mathrm{K}$ & M & & 2 \\
\hline $\mathbf{S}$ & . & $\mathbf{L}$ & . & . & $\mathbf{S}$ & . & . & M & $\mathrm{N}$ & & 2 \\
\hline D & . & $\mathbf{L}$ & . & . & $\mathbf{S}$ & . & . & L & G & & 1 \\
\hline E & . & $\mathrm{R}$ & . & . & $\mathbf{S}$ & . & . & $\mathrm{F}$ & D & & 1 \\
\hline G & . & $\mathbf{L}$ & . & . & $\mathbf{S}$ & . & . & A & C & & 1 \\
\hline G & . & $\mathbf{L}$ & . & . & $\mathbf{S}$ & . & . & L & S & & 1 \\
\hline G & . & M & . & . & $\mathbf{S}$ & . & . & H & G & & 1 \\
\hline G & . & M & . & . & $\mathbf{S}$ & . & . & $\mathrm{M}$ & C & & 1 \\
\hline G & . & $\mathrm{T}$ & . & . & $\mathbf{S}$ & . & . & L & G & & 1 \\
\hline $\mathrm{Q}$ & . & $\mathrm{R}$ & . & & $\mathbf{S}$ & . & . & L & G & & 1 \\
\hline s & . & L & . & . & $\mathbf{S}$ & . & . & $\mathrm{F}$ & D & & 1 \\
\hline $\mathrm{Y}$ & . & L & . & . & $\mathbf{S}$ & . & . & M & D & & 1 \\
\hline Y & & $\mathrm{R}$ & & & $\mathbf{S}$ & & & L & $\mathrm{N}$ & & 1 \\
\hline G/S & $\mathbf{L}$ & $\mathrm{L} / \mathrm{M}$ & V & W & $\mathbf{S}$ & D & $\mathbf{E}$ & $\mathrm{L} / \mathrm{H}$ & & & \\
\hline
\end{tabular}

${ }^{a}$ Bold characters indicate redundant residues in the second (L2) and third (L3) sublibrary.

${ }^{b}$ Number of clones sequenced in the biopanning. 


\section{FIGURES}

A

B
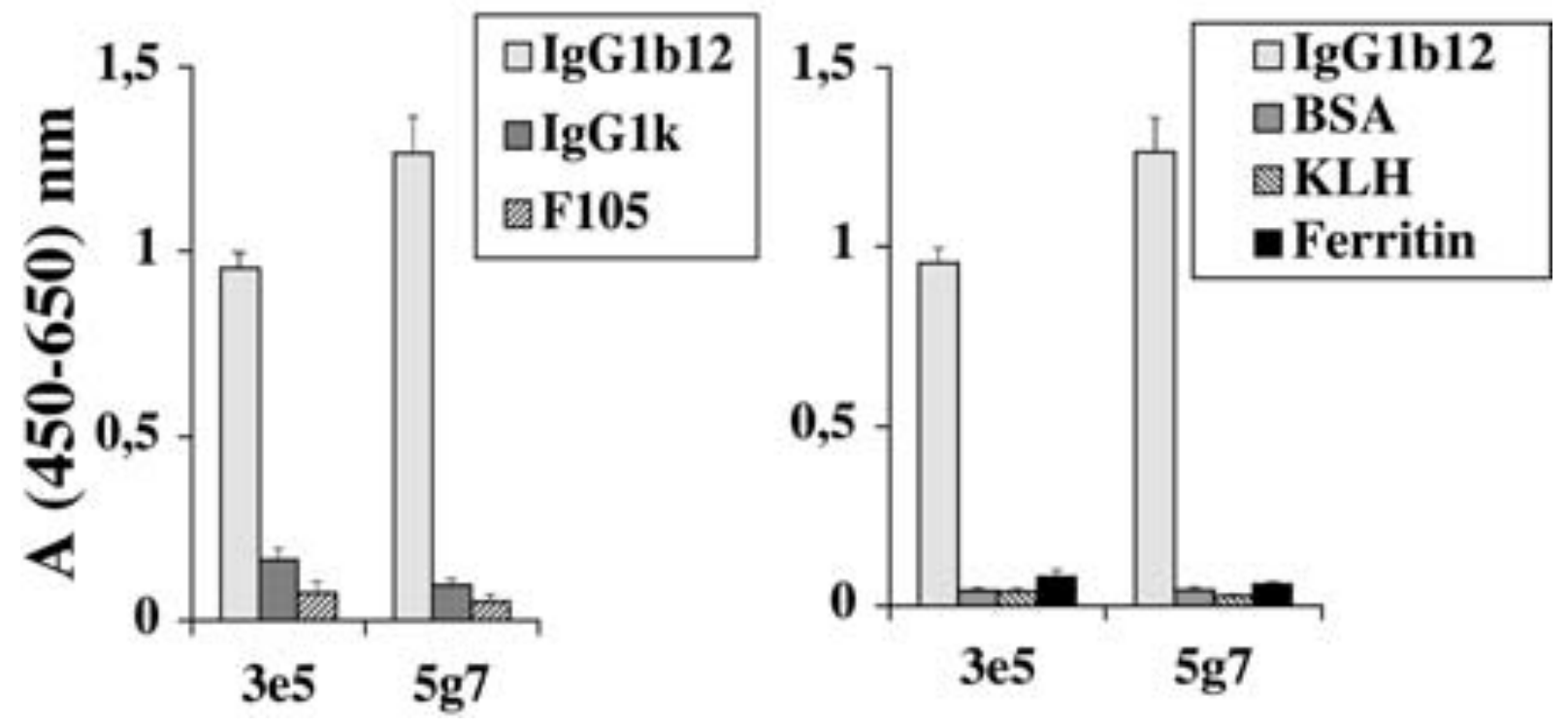

Dorgham et al. Figure 1 


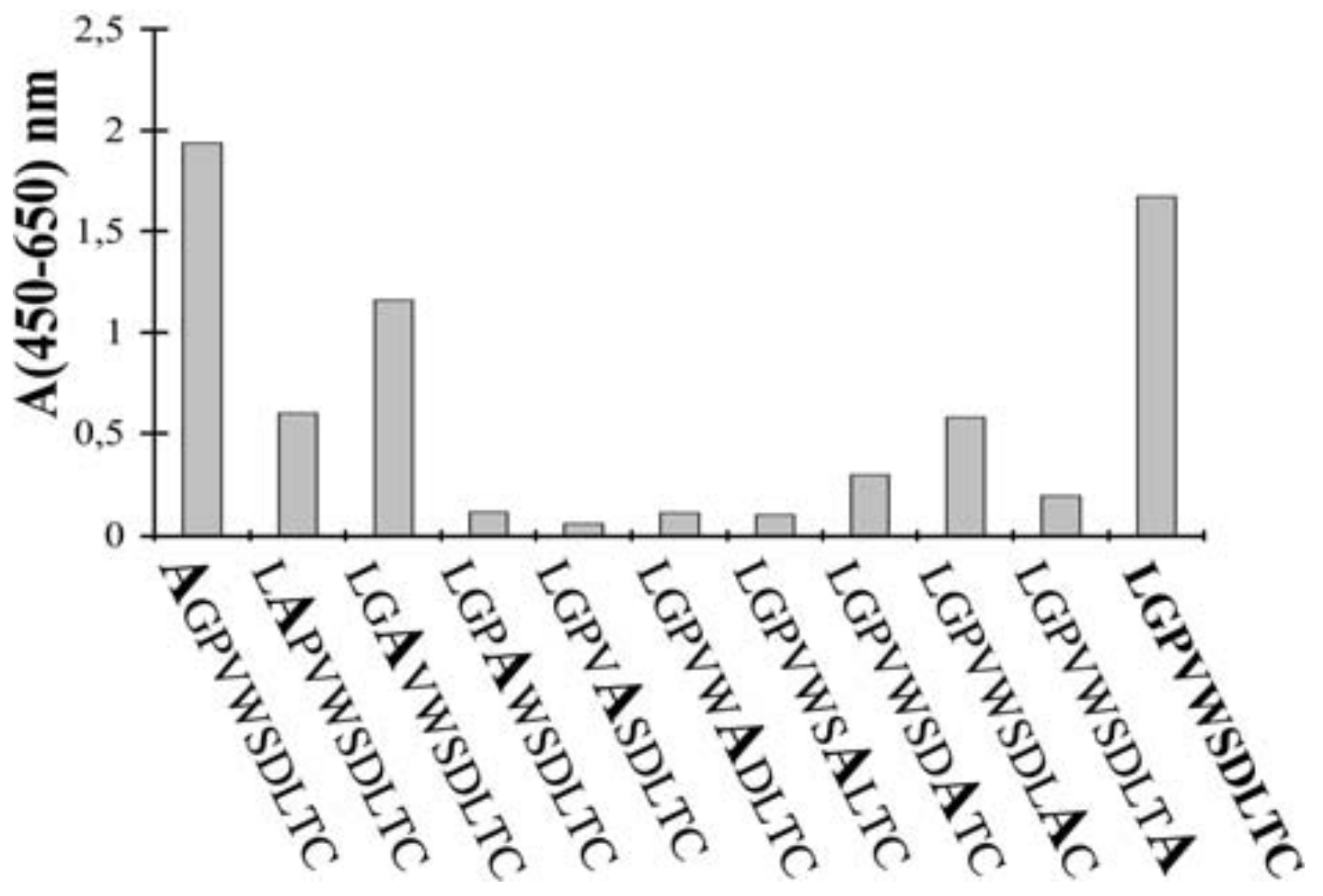

Dorgham et al. Figure 2 


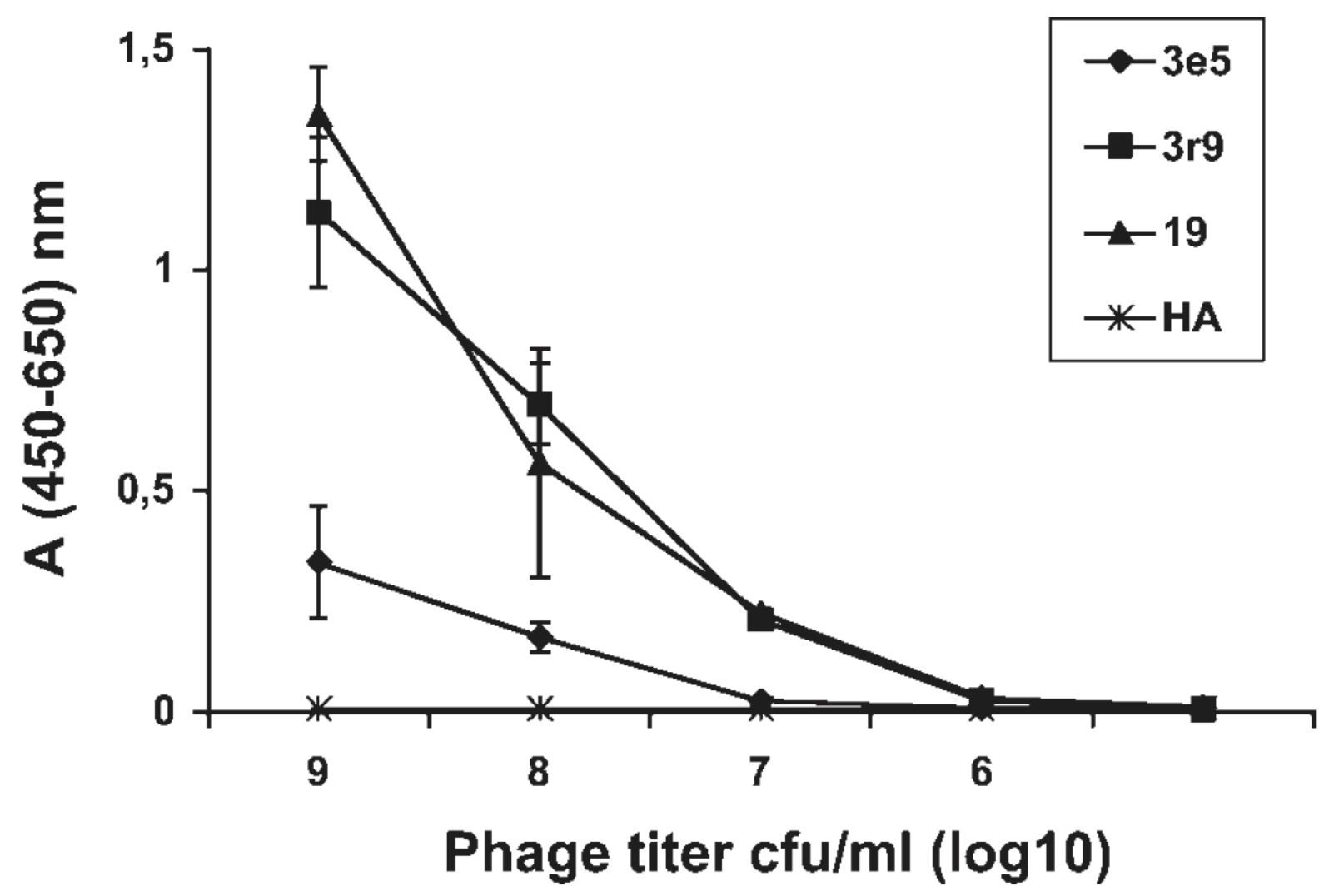

Dorgham et al. Figure 3 


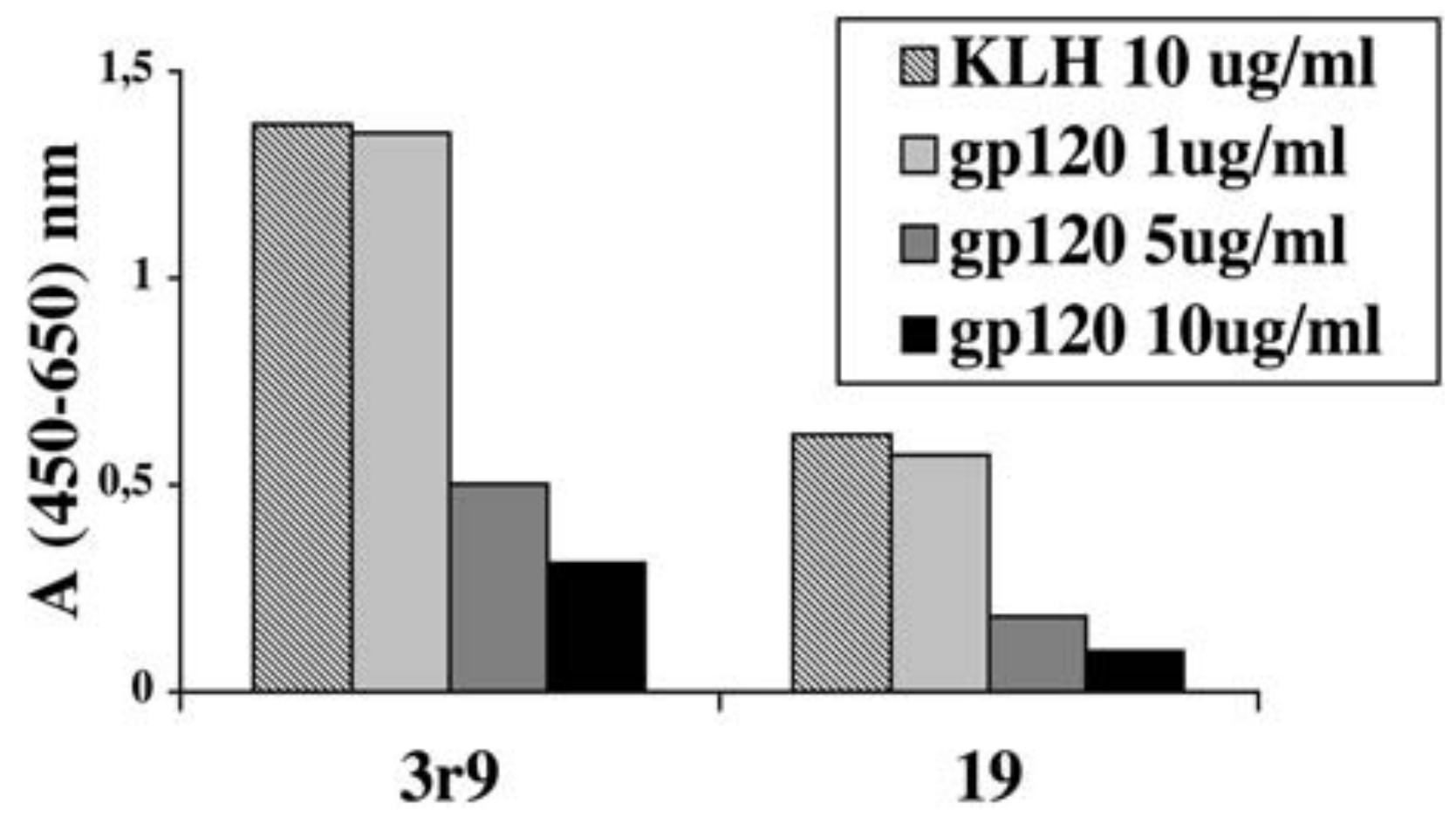

Dorgham et al. Figure 4 

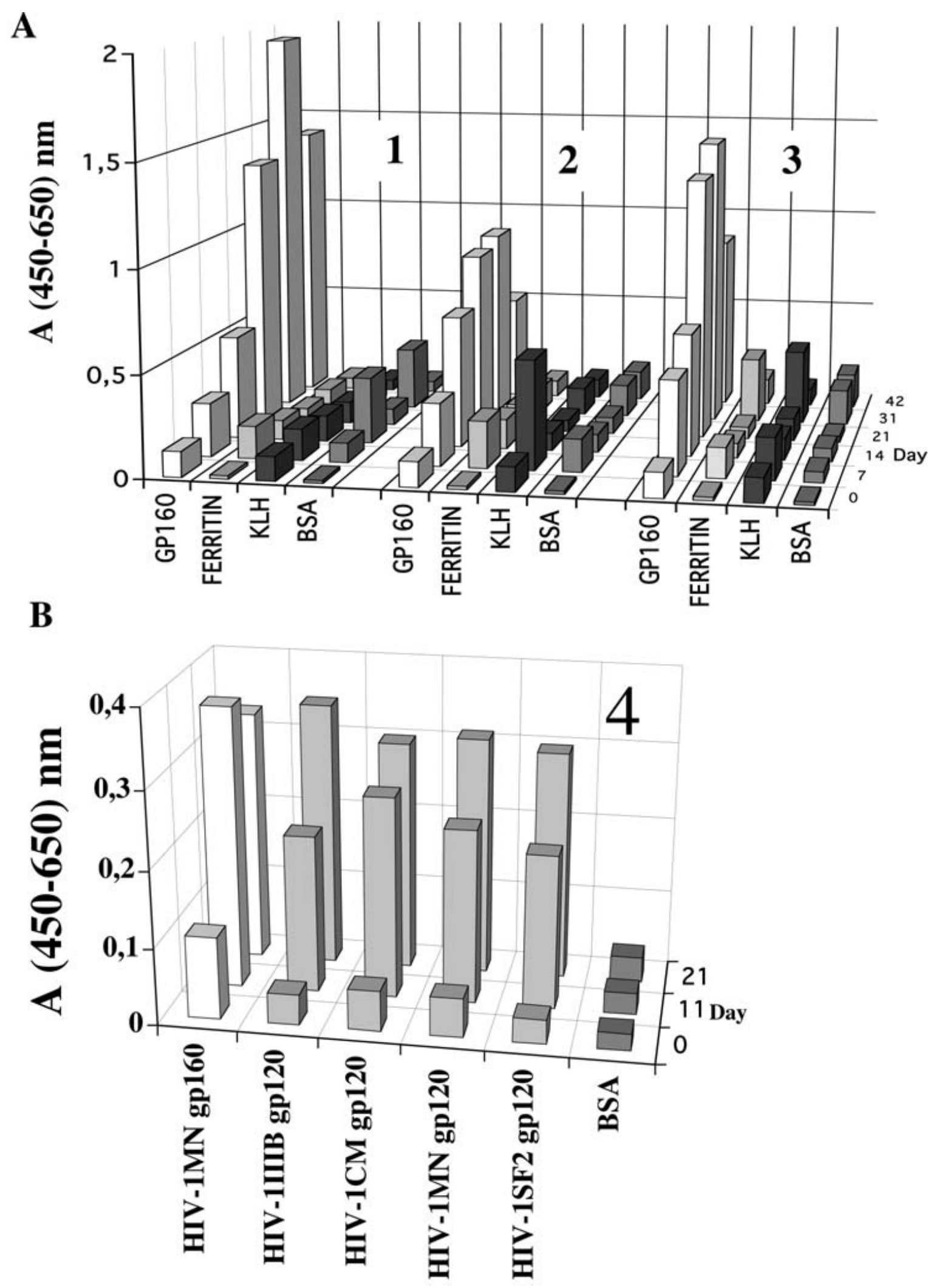

Dorgham et al. Figure 5 


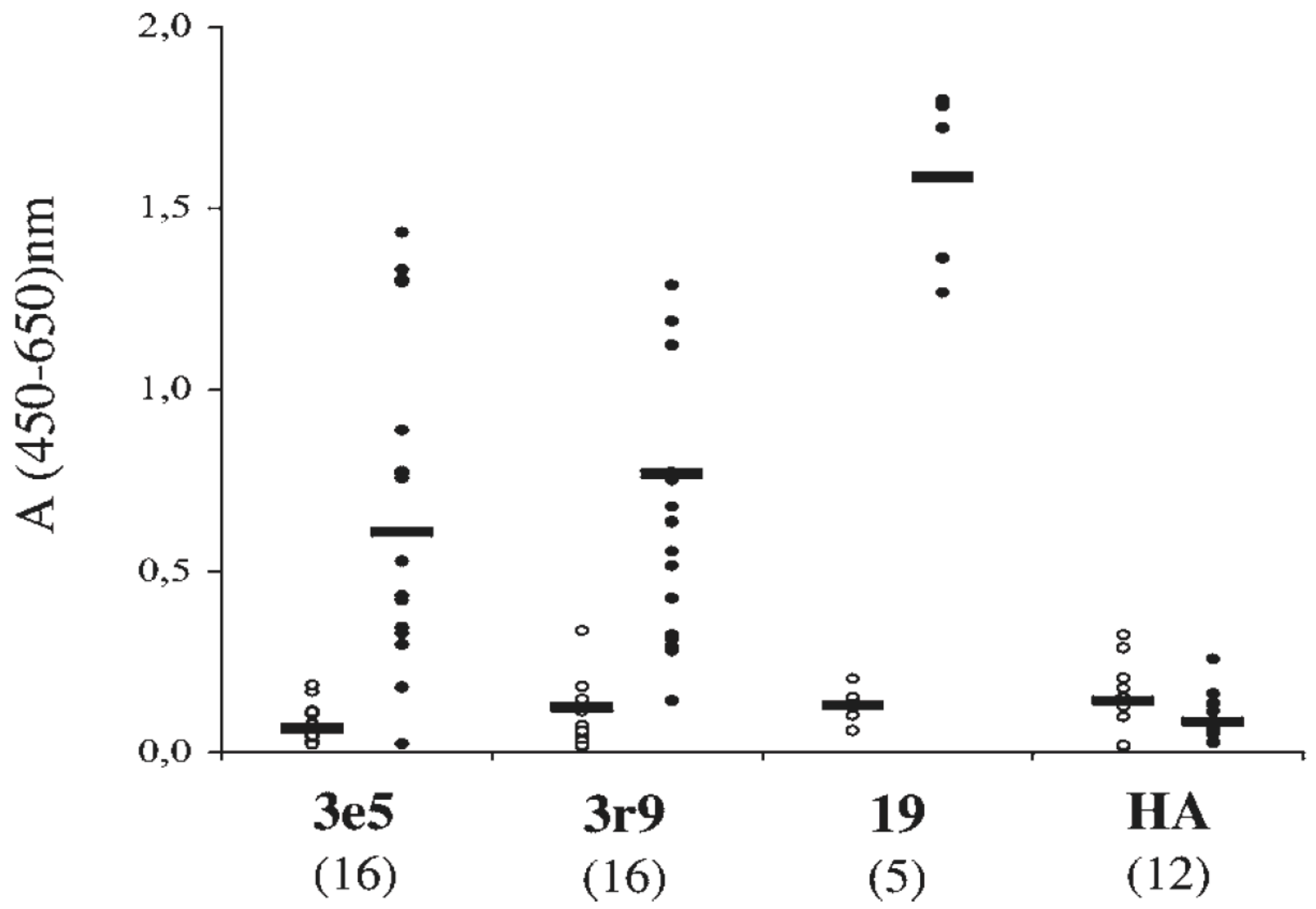

Dorgham et al. Figure 6 


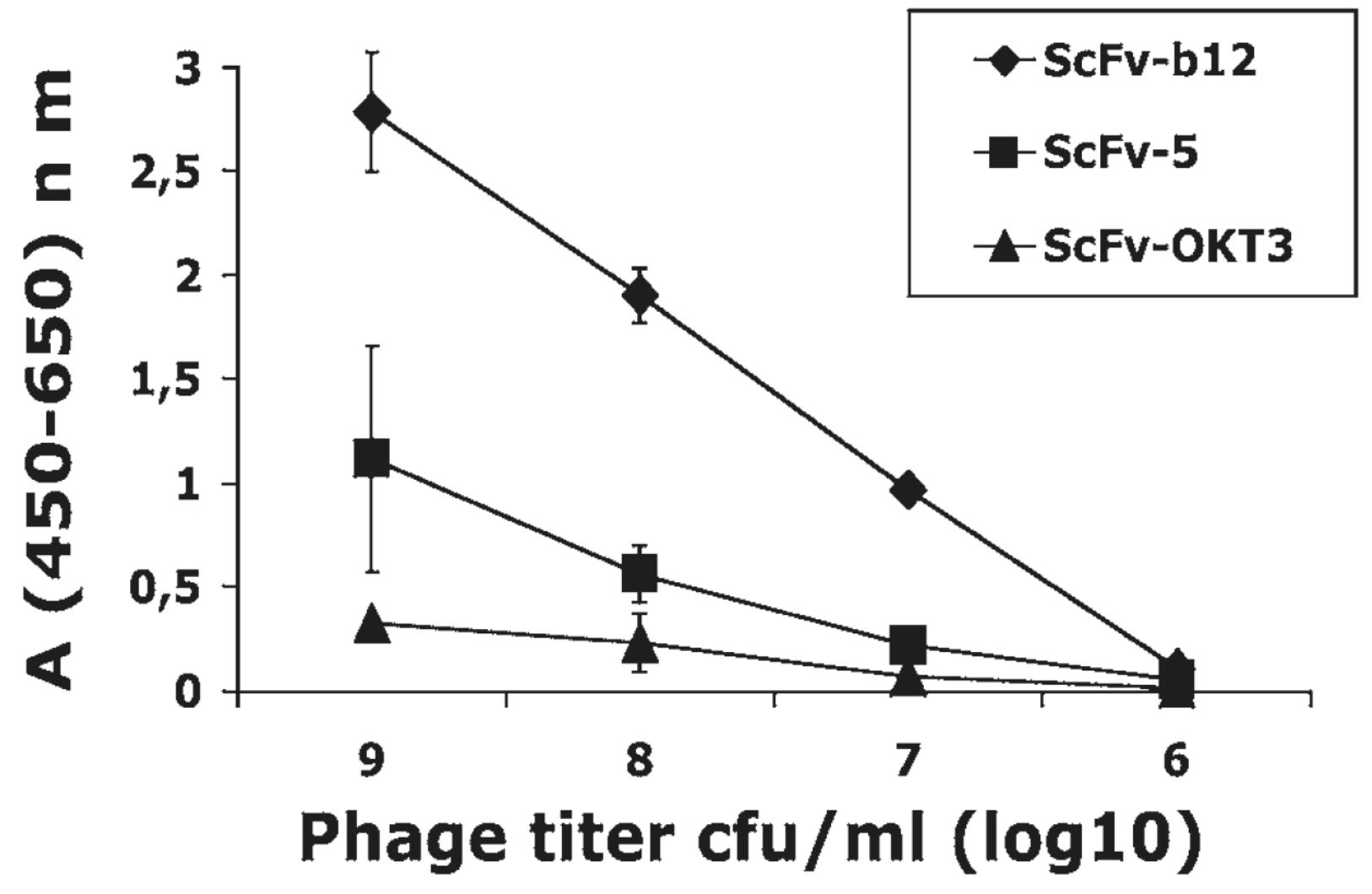

Dorgham et al. Figure 7 


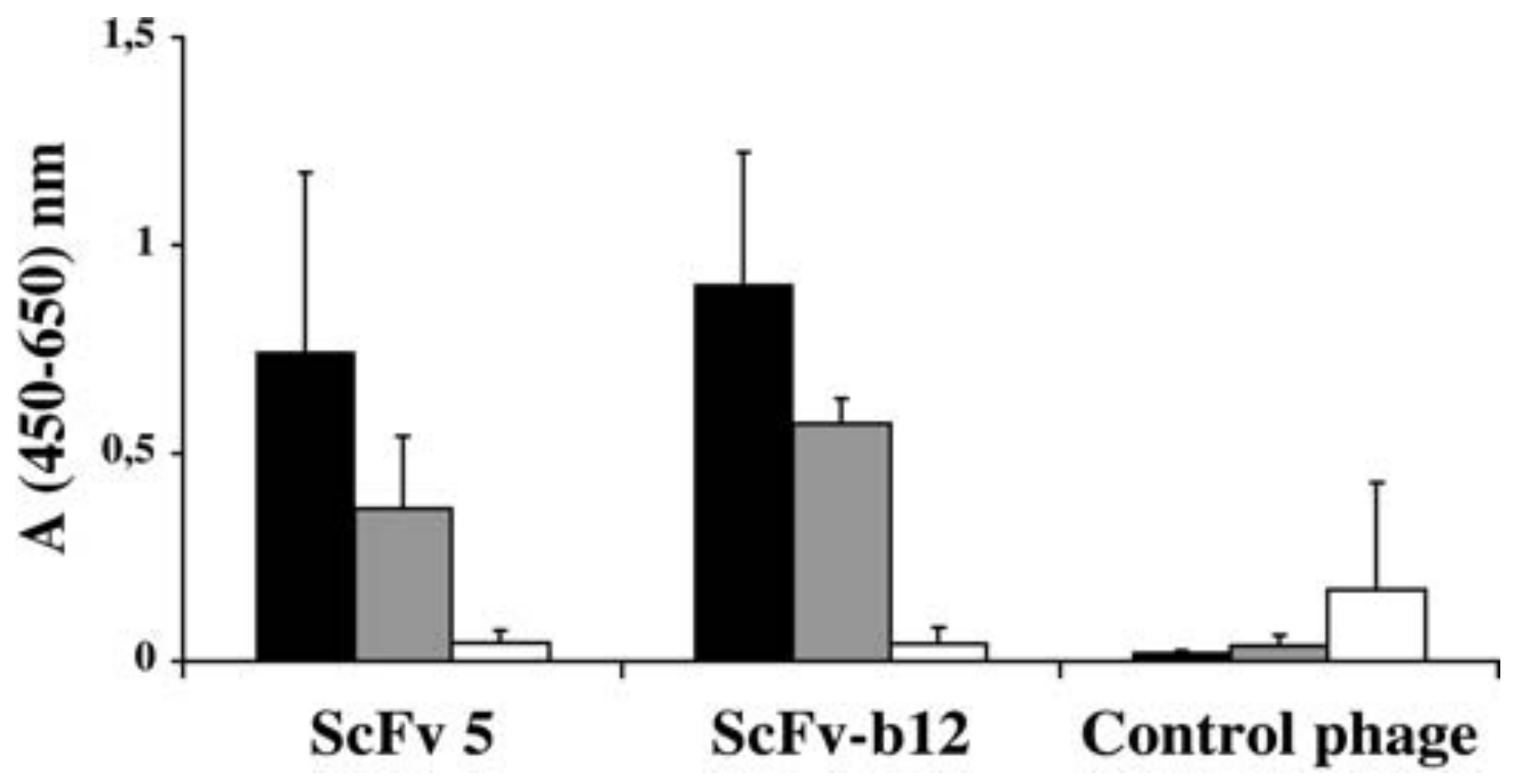

Dorgham et al. Figure 8 